\title{
Persetujuan Majelis Kehormatan Notaris Atas Pemanggilan Notaris Dalam Pemeriksaan Tindak Pidana
}

\author{
Moeh Angga Nugraha \\ Magister Kenotariatan Fakultas Hukum Universitas Islam Indonesia Yogyakarta Indonesia \\ Jln. Cik Di Tiro No. 1 Yogyakarta Indonesia \\ angga@gmail.com
}

Key Word:
Notary Honorary
Council; $\quad$ Public
Notary;
Constitutional Court
Decision

Abstract

Article 66 paragraph 1 of Law Number 2 of 2014 on Notary Position is intended to provide protection for notaries in the running of their profession. On the other hand, the article has disabled legal enforcers from immediately summoning or asking for an authentic deed made by a notary without the approval of the Notary Honorary Council (MKN). In response, material review of the article was conducted and it was ruled in the decision of the Constitutional Court Number 16/PUU-XVIII/2020. Derived from this description, the first problem arises, whether MKN can hinder the criminal examination process? Second, has the Constitutional Court's decision been satisfied as a decision based on justice, expediency and legal certainty? This is a normative legal research and with study through the statutory, conceptual, and case approaches. The results of this study conclude that first, the authority of the MKN in Article 66 of the UUJNP does not considerably hinder the law enforcement process and is part of the protection of the notary profession. Second, the Constitutional Court's decision has provided benefits for the general public who use notary services while maintaining the authority of the MKN. Then in terms of legal certainty, Article 66 becomes the basis for the limits of the MKN's authority to provide approval for investigators, public prosecutors and judges in summoning a notary or examining other files for judicial purposes

Kata-kata Kunci:
Majelis
Kehormatan
Notaris; Notaris;
Putusan
Mahkamah
Konstitusi

\section{Abstrak}

Putusan Pasal 66 ayat 1 Undang-Undang Nomor 2 Tahun 2014 tentang Jabatan Notaris dimaksudkan untuk melindungi notaris dalam pelaksanaan profesinya. di sisi lain, pasal tersebut membuat pengak hukum tidak serta merta melakukan pemanggilan atau meminta akta otentik yang dibuat oleh notaris tanpa persetujuan Majelis Kehormatan Notaris (MKN). Oleh karenanya terdapat pihak yang melakukan uji materiil terhadap pasal tersebut dan diputus dalam putusan Mahkamah Konstitusi Nomor 16/PUU-XVIII/2020. Dari penjabaran tersebut, muncul permasalah pertama, apakah MKN dapat menghalangi proses pemeriksaan pidana? Kedua, apakah Putusan MK tersebut telah memenuhi sebagai putusan berdasarkan keadilan, kemanfaatan dan kepastian hukum? Penelitian ini merupakan penelitian normatif dan dikaji melalui pendekatan perundang-undangan, konsep, dan kasus. Adapun hasil dari penelitian ini disimpulkan pertama, kewenangan MKN dalam Pasal 66 UUJNP tidak dianggap menghalangi proses penegakan hukum dan menjadi bagian dari perlindungan terhadap profesi notaris. Kedua, Putusan MK tersebut telah memberikan kemanfaatan bagi masyarakat umum pengguna jasa notaris dengan tetap mempertahankan kewenangan MKN. Kemudian, dalam hal kepastian hukum, pasal 66 tersebut menjadi dasar batas kewenangan MKN memberikan persetujuan bagi penyidik, penuntut umum dan hakim dalam melakukan pemanggilan terhadap notaris ataupun memeriksa berkasberkas lain untuk keperluan peradilan. 


\section{Pendahuluan}

Notaris dalam menjalankan profesinya tidak selalu lancar mulus akan tetapi tidak jarang terdapat notaris terkena permasalahan hukum atas tindakannya dalam pembuatan akta atau tindakan lainnya. Jika Notaris terkena proses hukum maka Notaris harus memberikan keterangan dan kesaksian menyangkut isi akta yang dibuatnya. Notaris dalam memberikan keterangan dan kesaksian terkait isi akta kepada penyidik atau penuntut umum harus mendapatkan ijin terlebih dahulu kepada Majelis Kehormatan Notaris (selanjutnya disebut MKN). Dalam hal ini MKN diatur dalam Pasal 66 ayat (1) Undang-Undang Nomor 2 Tahun 2014 tentang Jabatan Notaris (selanjutnya disebut UUJNP) yaitu:

1) Untuk kepentingan proses peradilan, penyidik, penuntut umum, atau hakim dengan persetujuan Majelis Kehormatan Notaris berwenang:

a. mengambil fotokopi Minuta Akta dan/atau surat-surat yang dilekatkan pada Minuta Akta atau Protokol Notaris dalam penyimpanan Notaris; dan

b. memanggil Notaris untuk hadir dalam pemeriksaan yang berkaitan dengan Akta atau Protokol Notaris yang berada dalam penyimpanan Notaris.

2) Pengambilan fotokopi Minuta Akta atau surat-surat sebagaimana dimaksud pada ayat (1) huruf a, dibuat berita acara penyerahan.

3) Majelis kehormatan Notaris dalam waktu paling lama 30 (tiga puluh) hari kerja terhitung sejak diterimanya surat permintaan persetujuan sebagaimana dimaksud pada ayat (1) wajib memberikan jawaban menerima atau menolak permintaan persetujuan.

4) Dalam hal majelis kehormatan Notaris tidak memberikan jawaban dalam jangka waktu sebagaimana dimaksud pada ayat (3), majelis kehormatan Notaris dianggap menerima permintaan persetujuan."

Berdasarkan pada Pasal 66 UUJNP tidak serta merta penegak hukum dapat melakukan pemanggilan atau meminta akta otentik yang dibuat oleh notaris. Dengan adanya Pasal 66 UUJNP maka pemanggilan Notaris untuk proses penyidikan yang diduga melakukan tindak pidana harus mendapatkan persetujuan terlebih dahulu dari Majelis Kehormatan Notaris. Adapun prosedur untuk mendapatkan persetujuan dari MKN dengan cara Penyidik harus memberikan surat permohonan kepada Majelis Kehormatan Notaris untuk melakukan proses penyidikan kepada Notaris yang diduga melakukan tindak pidana. Dalam hal ini MKN diberikan jangka waktu selama tiga puluh hari untuk memberikan jawaban kepada penyidik apakah menerima atau menolak permohonan penyidikan. ${ }^{1}$

Sebelum terbitnya Pasal 66 UUJNP, pemerintah menerbitkan Undang-Undang Nomor 30 Tahun 2004 tentang Jabatan Notaris (selanjutnya disebut UUJN) pada ketentuan tersebut terdapat Pasal 66 ayat (1) yang menjadi permasalahan sehingga munculah gugatan judicial review ke MK. Pada 28 Mei 2013 MK mengeluarkan putusan Nomor 49/PUU-X/2012 yang tidak memberlakukan lagi Pasal 66 ayat (1) UUJN.

1 Azisia Pancaputri, Rachmaad Syafaat, Istislam, Perlindungan Hukum Bagi Notaris Dalam Proses Penyidikan Terhadap Notaris Yang Diduga Melakukan Tindak Pidana Terkait Dengan Putusan Mahkamah Konstitusi Nomor 49/PUU-X/2012 (Studi Di Kantor Polisi Resort Kota Malang), Jurnal Medianeliti, didownload pada https://media.neliti.com/media/publications/118683-ID-perlindungan-hukum-bagi-notaris-dalam-pr.pdf, hlm. 4 
Sehingga mengakibatkan pemanggilan Notaris tidak memerlukan jawaban atau persetujuan dari Majelis Pengawas Daerah (selanjutnya disebut MPD). Putusan MK Nomor 49/PUU-X/2012 membawa konsekuensi yuridis penyidik dapat langsung memanggil Notaris untuk segera datang dalam proses penyidikan. ${ }^{2}$

Putusan Mahkamah Konstitusi Nomor 49/PUU-X/2012 memutuskan telah menghapus atau mengakhiri kewenangan Majelis Pengawas Daerah yang terdapat dalam Pasal 66 ayat (1) Undang-Undang Nomor 30 Tahun 2004, Putusan MK Nomor 49/PUU-X/2012 tidak memberikan perlindungan bagi notaris dalam menjalankan profesinya. Pencabutan Pasal 66 ayat (1) UUJN tidak berlangsung lama. Pada tahun 2014 pemerintah menerbitkan UUJNP yang menghidupkan kembali Pasal 66 ayat (1) yang berisi: "Untuk kepentingan proses peradilan, penyidik, penuntut atau hakim dengan persetujuan Majelis Kehormatan Notaris."

Adapun perbedaan Pasal 66 ayat (1) UUJN dengan UUJNP yaitu adanya Majelis Kehormatan Notaris (selanjutnya disebut MKN) dan pada UUJN menyatakan bahwa pemanggilan Notaris untuk proses penyidikan harus dengan persetujuan Majelis Pengawas Daerah sedangkan UUJN yang baru hanya memberikan perubahan pada lembaga yang berwenang memberikan persetujuan untuk proses penyidikan yaitu merubahnya menjadi MKN.

Putusan MK Nomor 49/PUU-X/2012 menjadi landasan atau motivasi pihak yang dirugikan untuk kembali mengajukan gugatan judicial review. Gugatan Judicial review Pasal 66 ayat (1) UUJNP diajukan oleh Persatuan Jaksa Indonesia (PJI) dalam hal ini diwakili oleh Setia Untung Arimuladi, adapun latar belakang PJI melakukan gugatan judicial review yaitu PJI merasakan dirugikan dengan berlakunya ketentuan pasal a quo karena jaksa di seluruh Indonesia telah atau setidaknya berpotensi untuk dipersulit atau dihalangi dalam melaksanakan tugas dan kewenangannya sebagai penuntut umum.

Pada Juni 2020 Mahkamah Konstitusi memutuskan menolak uji materi Pasal 66 ayat (1) UUJNP, permohonan Pemohon I, Pemohon II, Pemohon III, IV dan Pemohon V, yang dibacakan oleh Anwar Usman pada putusan Nomor 16/PUU-XVIII/2020/2020. Putusan MK Nomor 16/PUU-XVIII/2020 memberikan kepastian hukum dan perlindungan hukum bagi Notaris berbeda dengan Putusan Mahkamah Konstitusi Nomor 49/PUU-X/2012.

\section{Rumusan Masalah}

Berdasarkan latar belakang masalah sebagaimana yang telah diuraikan di atas, maka dapat dirumuskan tiga rumusan masalah yakni, pertama, apakah Majelis Kehormatan notaris dapat menghalangi proses pemeriksaan pidana? Kedua, apakah Putusan MK Nomor Nomor 16/PUU-XVIII/2020 telah memenuhi sebagai putusan berdasarkan keadilan, kemanfaatan dan kepastian hukum? Ketiga, apakah Pasal 66 ayat (1) UUJNP menghalangi proses penegakan hukum pidana? 


\section{Tujuan Penelitian}

Adapun tujuan dari penelitian ini adalah, pertama, untuk mengetahui Putusan MK Nomor 16/PUU-XVIII/2020 telah memenuhi sebagai putusan berdasarkan keadilan, kemanfaatan dan kepastian hukum. Kedua, untuk mengetahui Majelis Kehormatan notaris dapat menghalangi proses pemeriksaan pidana sehingga persatuan jaksa mengajukan gugatan judicial review ke Mahkamah Konstitusi. Ketiga, untuk mengetahui Pasal 66 ayat (1) UUJN menghalangi proses penegakan hukum pidana.

\section{Metode Penelitian}

Penulisan penelitian ini menggunakan metode penelitian yuridis normatif dengan pendekatan peraturan perundang-undangan (statute approach), pendekatan konsep (Conseptual Approach), dan pendekatan kasus (Case Approach) menggunakan putusan MK Nomor 16/PUU-XVIII/2020.3 Bahan yang digunakan dalam penelitian ini bersumber pada bahan hukum primer, bahan hukum sekunder maupun bahan hukum tersier. Bahan yang diperoleh dalam penelitian ini dianalisis dengan menggunakan metode kualitatif, ${ }^{4}$ yaitu metode analisis data dengan cara mengelompokkan dan menyeleksi data yang diperoleh dari penelitian lapangan menurut kualitas dan kebenarannya kemudian disusun secara sistematis, yang selanjutnya dikaji dengan metode berfikir secara deduktif.

\section{Hasil Penelitian dan Pembahasan}

\section{Peran Majelis Kehormatan dalam Pemeriksaan Pidana yang Dilakukan oleh Notaris}

Pada 2014 pemerintah menerbitkan Undang-Undang Nomor 2 Tahun 2014 tentang Jabatan Notaris sebagai pengganti UU Nomor 8 Tahun 2004 sebagai pelaksana pengawasan, pemeriksaan dan penjatuhan sanksi bagi notaris yang didalammnya terdapat Lembaga Majelis Kehormatan Notaris (MKN). MKN merupakan badan yang bersifat independen dalam mengambil keputusan yang mempunyai tugas dan kewajiban untuk memberikan bimbingan atau pembinaan dalam rangka memperkuat institusi Notaris dalam menegakkan UUJN bagi setiap orang yang menjalankan jabatan sebagai Notaris. ${ }^{5}$ Landasan dibentuknya MKN karena adanya Putusan Mahkamah Konstitusi Republik Indonesia Nomor 49/PUU-X/2012 dengan alasan bahwa bertentangan dengan Undang-Undang Dasar Negara Republik Indonesia Tahun 1945, dengan adanya putusan MK tersebut maka pemerintah menerbitkan UU Nomor 2 Tahun 2014 Tentang Jabatan Notaris. Adapun MKN mempunyai kewenangan dan tugas sebagaimana tertuang dalam Pasal 66 UUJN P yaitu sebagai berikut:

1) Untuk kepentingan proses peradilan, penyidik, penuntut umum, atau hakim dengan persetujuan Majelis Kehormatan Notaris berwenang:

\footnotetext{
${ }^{3}$ Ibid., hlm. 89

${ }^{4}$ Abdul Kadir Muhammad, Hukum Dan Penelitian Hukum, Citra Aditya Bakti, Bandung, 2004, hlm. 50.

${ }^{5}$ Evi Apita Maya, Kedudukan Dan Kewenangan Majelis Kehormatan Notaris Dalam Pembinaan Notaris, Jurnal IUS, Volume 5, Nomor 2, Agustus, 2017, hlm 256
} 
a. Mengambil fotokopi minuta akta dan/atau surat-surat yang dilekatkan pada minuta akta atau protokol Notaris dalam penyimpanan Notaris; dan

b. Memanggil Notaris untuk hadir dalam pemeriksaan yang berkaitan dengan akta atau protokol Notaris yang berada dalam penyimpanan Notaris.

MKN tertuang selain pada UUJNP diatur dalam Peraturan Menteri Hukum dan Hak Asasi Manusia Nomor 7 Tahun 2016 tentang Majelis Kehormatan Notaris. Landasan hukum tersebut memberikan peran yang penting dalam pemeriksaan dan perlidungan hukum bagi notaris yang diduga melakukan pelanggaran pidana. Peran MKN melakukan persetujuan kepada penegak hukum dalam hal ini penyidik, penuntut umum, atau hakim hendak memanggil Notaris untuk kepentingan penyidikan, penuntutan, atau proses peradilan. Peraturan Menteri Hukum dan Hak Asasi Manusia Nomor 7 Tahun 2016 tentang Majelis Kehormatan Notaris memberikan aturan terkait dengan tata cara atau prosedur penegakan hukum pidana yang dilakukan oleh notaris serta peran penting MKN di dalamnya, yaitu sebagai berikut:

a. Berdasarkan Pasal 23 Permenkumham a quo menyatakan bahwa permohonan diajukan oleh penyidik, penuntut umum atau hakim kepada Ketua MKN Wilayah, sesuai dengan wilayah kerja Notaris yang bersangkutan. Pasal 23 Permenkumham a quo wajib ditembuskan kepada notaris untuk melakukan tindakan berupa: 6

1) Pemeriksaan terhadap notaris (termasuk Notaris Pengganti dan Pejabat Sementara Notaris) untuk hadir dalam penyidikan, penuntutan dan proses peradilan yang berkaitan dengan akta atau protokol notaris yang berada dalam penyimpanan notaris;

2) Pengambilan fotokopi minuta akta dan/atau surat surat yang dilekatkan pada minuta akta atau protokol notaris dalam penyimpanan notaris;

3) Pengambilan minuta akta dan atau surat surat yang dilekatkan pada minuta akta notaris atau protokol notaris dalam penyimpanan notaris.

b. Berdasarkan Pasal 23 ayat 4 Permenkumham a quo menyatakan bahwa atas permohonan diajukan oleh penyidik, penuntut umum atau hakim, Ketua MKN Wilayah wajib memberikan jawaban berupa persetujuan atau penolakan terhadap permohonan penyidik, penuntut umum atau hakim, dalam jangka waktu paling lambat 30 hari sejak tanggal diterimanya permohonan, lebih lanjut Pasal 23 ayat 5 Peraturan Menteri Hukum dan Hak Asasi Manusia Nomor 7 Tahun 2016 tentang Majelis Kehormatan Notaris yaitu Jika jangka waktu 30 hari sejak permohonan diterima terlampaui, Ketua MKN Wilayah tidak atau belum memberikan jawaban, maka dianggap Ketua MKN Wilayah menerima permintaan persetujuan yang diajukan oleh Penyidik, Penuntut Umum atau Hakim.

Pada praktiknya peran MKN dalam adanya laporan atau permintaan izin oleh penegak hukum terkait laporan tindak pidana yang dilakukan oleh notaris, MKN akan membentuk Tim Pemeriksa yang terdiri dari 3 orang yang mewakili tiap unsur anggota MKN Wilayah kemudian dibuatkan jadwal untuk sidang pemeriksaan dan panggilan para

${ }^{6}$ Endah Sumiarti, Djodi Suranto, Yennie K Milano, Fungsi Majelis Kehormatan Notaris Ditinjau Dalam Perspektif Perlindungan Jabatan Notaris Dan Kepentingan Umum, Jurnal Pakuan Law Review, Volume 1 Nomor 2, Julli - Desember 2015, e ISSN, hlm. 157 
pihak. ${ }^{7}$ Peran tim pemeriksa dalam hal ini mempunyai kewenangan untuk menyatakan menolak permintaan penegak hukum atau menerima permintaan penegak hukum untuk diadakan pemanggilan notaris oleh penegak hukum. Terkait MKN menerima pemanggilan notaris oleh penegak hukum maka dalam hal ini MKN telah terjadi pelanggaran jabatan oleh notaris dalam menjalankan tugasnya. Konsekuensi yuridis pemanggilan notaris oleh penegak hukum tanpa didahului oleh pemeriksaan MKN maka pemanggilan tersebut illegal dan melanggar hukum. Menurut pendapat Soerjono Soekanto persetujuan yang diberikan oleh MKN kepada penegak hukum memperhatikan unsur-unsur yaitu, peraturan, aparatur, pelaksanaan, dan kondisi maysarakat.

Peran MKN dalam memberikan perlindungan notaris yang diduga melakukan perbuatan pidana tidak serta mutlak harus melalui MKN terlebih dahulu akan tetapi notaris dapat datang secara langsung kepada penegak hukum guna memberikan keterangan tanpa didahului oleh pemeriksaan oleh MKN. Perlindungan hukum MKN terhadap notaris diberikan sebagai perlindungan jabatan notaris sebagai pejabat umum, akan tetapi jika notaris melakukan kesalahan atau kelalaian atas nama pribadi maka notaris tidak akan diberikan perlindungan hukum oleh MKN. Lebih lanjut menurut pendapat Mustafa dalam penelitian Juleni menyatakan bahwa karena apa yang dilakukan Notaris tersebut justru tidak sesuai dengan frase 'kehormatan' pada akronim dari MKN yang seharusnya Notaris menjaga harkat, martabat, kehormatan dan keluhuran jabatan Notaris bukan merusak nama dan marwah dari jabatan Notaris. ${ }^{8}$

Pada Januari 2020 Persatuan Jaksa Indonesia yang diwakili Setia Untung Arimuladi mengajukan pendaftaran gugatan judicial review ke Mahkamah Konstitusi yang diterima di kepaniteraan Mahkamah Konstitusi. Mengajukan permohonan judicial review Pasal 66 ayat (1) UUJNP. Adapun alasan gugatan yang diajukan oleh pemohon didasarkan pada dalam Pasal 66 UUJNP menempatkan MKN memiliki kewenangan mutlak dan final untuk menyetujui atau tidak menyetujui pemanggilan notaris untuk hadir dalam pemeriksaan perkara. Hal tersebut menyebabkan penyidik, penuntut umum, maupun hakim tidak dapat melakukan upaya hukum lebih lanjut. ${ }^{9}$ Berdasarkan pendapat pemohon menyatkan bahwa Pasal 66 a quo menjadikan Notaris sebagai suatu subjek khusus yang kedudukannya menjadi superior dalam hukum. Keharusan atau persetujuan Majelis Kehormatan Notaris tersebut bertentangan dengan prinsip independensi dalam proses peradilan (judiciary indepence), kewajiban seorang Notaris sebagai warga negara yang memiliki kedudukan sama di hadapan hukum (equality before the law), dan prinsip kedudukan yang sama di hadapan pemerintahan (equal protection) sebagaimana yang dijamin oleh UUD 1945.10 Lebih lanjut pemohon memandang bahwa dalam ketentuan Pasal 66 UUJNP bertentangan dengan Asas

${ }^{7}$ Udi Hernawan \& Munssyarif Abdul Chalim, Kewenangan Majelis Kehormatan Notaris Wliayah Dalam Memberikan Persetujuan Terhadap Pemanggilan Notaris Oleh Penegak Hukm, Jurnal Akta, Volume 4 Nomor 3 , Tahun 2017, hlm. 451.

8 Juleni, Implementasi Pemeriksaan Notaris Oleh Majelis Kehormatan Notaris Atas Dugaan Melakukan Tindak Pidana Berdasarkan Peraturan Menteri Hukum dan Hak Asasi Manusia Nomor 7 Tahun 2016 tentang Majelis Kehormatan Notaris, Tesis, Program Magister Kenotariatan, Fakultas Hukum, Universitas Sebelas Maret, Surakarta, hlm. 78

${ }^{9}$ Lihat Resume Perkara Putusan Mahkamah Konstitusi Nomor 16/PUU-XVIII/2020, didownload pada 25 Juli 2020, hlm .6

${ }^{10}$ Ibid., hlm. 7 
Dominus Litis karena tindakan MKN yang dapat memilih siapa yang diperbolehkan untuk memberikan atau tidak memberikan keterangan di persidangan menjadikannya sebagai lembaga yang memiliki peran mengendalikan suatu perkara. ${ }^{11}$

PJI memandang bahwa MKN layaknya hakim yang dapat memutuskan perbuatan notaris tersebut bukan tindak pidana, bahkan ironisnya, putusan MKN bersifat final tanpa adanya mekanisme upaya hukum lainnya sebagaimana dalam proses peradilan yaitu banding dan kasasi. Berdasarkan data yang dimiliki oleh Reda Mantovani data Risk Exposure Tindak Pindana Pencucian Uang (TPPU) yang diterbitkan Direktorat Pemeriksaan, Riset dan Pengembangan Pusat Pelaporan Analisa dan Transaksi Keuangan (PPATK) terkait notaris periode 2015-2019, setidaknya tercatat 420 Suspicious Transaction Report (STR), yaitu dengan mayoritas terlapor mencapai 348 STR $(83 \%)$ yang diduga sebagai notaris. ${ }^{12}$

Adapun pandangan hakim MK dalam pertimbangan hakim terkait dengan gugatan pemohon menyatakan bahwa Pasal 66 ayat (4) UUJNP sangat diperlukan dalam menciptakan kepastian hukum yang adil terhadap batas kewenangan MKN memberikan persetujuan bagi penyidik, penuntut umum dan hakim dalam melakukan pemanggilan terhadap notaris ataupun memeriksa berkas-berkas lain untuk keperluan peradilan sebagaimana dimaksud Pasal 66 ayat (1) UUJNP. Berdasarkan pertimbangan tersebut, maka Mahkamah berpendapat dalil Pemohon mengenai inkonstitusionalitas Pasal 66 ayat (1) dan ayat (4) UU Jabatan Notaris adalah tidak beralasan menurut hukum. ${ }^{13}$

Berdasarkan pada bunyi amar putusan yang menyatakan gugatan pemohon I tidak dapat diterima dan menolak permohonan Pemohon II untuk selain dan selebihnya, maka demi hukum tidak ada perubahan terhadap bunyi ketentuan Pasal 66 ayat (1) UUJNP.

Mencermati ketentuan dalam Pasal 66 ayat (1) maka untuk kepentingan proses peradilan, penyidik, penuntut umum, atau hakim dengan persetujuan majelis kehormatan Notaris, oleh karena itu penegak hukum pasca putusan MK Nomor 16/PUU-XVIII/2020 tetap harus mendapatkan ijin terlebih dahulu kepada MKN dalam melakukan panggilan terhadap notaris yang diduga melakukan tindak pidana. Putusan MK Nomor 16/PUU-XVIII/2020 memperkuat tugas dan tanggung jawab MKN pada Notaris sebagaimana diatur dalam Pasal 18 ayat (2) Permenkumham Nomor 7 Tahun 2016 tentang Majelis Kehormatan Notaris.

\section{Putusan MK Nomor 16/PUU-XVIII/2020 telah Memenuhi tebagai Putusan Berdasarkan Keadilan, Kemanfaatan dan Kepastian Hukum}

\section{Kepastian Hukum}

Pada Putusan MK Nomor Nomor 16/PUU-XVIII/2020 hakim memberikan kepastian hukum dimana berdasarkan UUJNP menegaskan bahwa Pasal 66 ayat (1) tetap berlaku dan MKN mempunyai kewenangan untuk melakukan proses peradilan, penyidik, penuntut umum, atau hakim dengan persetujuan majelis kehormatan Notaris. Hakim MK dalam melakukan pengujian UU selalu melakukan interprestasi atau

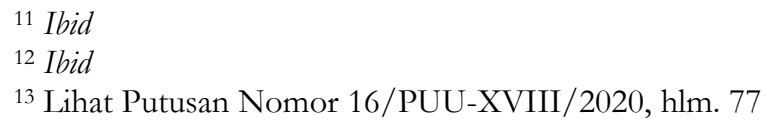


penafsiran. Penafsiran hakim MK yang didasarkan pada UUD merupakan bentuk kepastian hukum bahwa hakim MK terikat pada ketentuan atau Pasal-pasal UUD 1945, sebagaimana pendapat Sulardi, bahwa kepastian hukum menekankan agar peraturan harus ditegakkan sebagaimana yang diinginkan oleh bunyi peraturannya. Bahwa setiap orang mengharapkan hukum dapat diimplementasikan dalam peristiwa konkrit, sehingga pemberlakuannya tidak dibolehkan menyimpang, meskipun dunia ini runtuh namun hukum harus ditegakkan. ${ }^{14}$ Hakim MK tidak akan menyimpang dari UUD dalam memberikan putusannya.

Menurut Gustav Radrbuch sebagaimana dikutip oleh Sanjaya, terdapat empat dasar yang berhubungan dengan kepastian hukum yaitu sebagai berikut: 15

a. Bahwa hukum itu positif yakni perundang-undangan.

b. Bahwa hukum itu didasarkan pada fakta atau hukum yang ditetapkan itu pasti.

c. Bahwa kenyataan (fakta) harus dirumuskan dengan cara yang jelas sehingga menghindari kekeliruan dalam pemaknaan di samping mudah dilaksanakan.

d. Hukum positif tidak boleh mudah berubah.

Menurut Apeldoorn, kepastian hukum mempunyai dua segi, pertama mengenai soal dapat dibentuknya (bepaalbaarheid) hukum dalam hal-hal yang konkret. Artinya pihak-pihak yang mencari Keadilan ingin mengetahui hukum dalam hal yang khusus sebelum memulai perkara. Kedua, kepastian hukum berarti keamanan hukum. Artinya perlindungan bagi para pihak terhadap kesewenangan Hakim. ${ }^{16}$ Perlindungan hukum atau keamanan hukum dalam Putusan MK Nomor 16/PUU-XVIII/2020 yaitu dengan Hakim MK menolak gugatan Pemohon I dan Pemohon II, dalam hal ini membawa dampak kepastian hukum serta perlindungan hukum bagi notaris dalam melaksanakan tugas dan kewajibannya. Bentuk kepastian hukum diperkuatnya Pasal 66 ayat (1) UUJNP, adanya Putusan MK Nomor 16/PUU-XVIII/2020 maka penegak hukum tidak serta merta memanggil notaris jika ada dugaan tindak pidana tanpa melalui ijin MKN.

\section{Keadilan}

Keadilan merupakan hal yang abstrak atau filosofis tidak dapat dilihat atau dirasakan oleh seseorang. Pada putusan Mahkamah Konstitusi wajib menggali nilai-nilai yang hidup dimasyarakat yang berdasarkan Pancasila dan UUD 1945, oleh karena itu hakim MK dalam menjatuhkan putusan tidak hanya memandang terhadap keadilan bagi pemohon akan tetapi putusan Hakim MK dapat memberikan keadilan sosial, karena putusan MK akan berdampak kepada masyarakat luas. Sehingga dapat disimpulkan bahwa rasa keadilan Mahkamah terwujud dalam keadilan procedural maupun dalam keadilan substansial. Dalam keadilan prosedural telah terpenuhi keadilan yang

${ }^{14}$ Sulardi, Yohana Puspitasari Wardoyo, Op. Cit., hlm. 263

15 Sanjaya, A. W. Kewenangan penyidikan tindak pidana pencucian uang yang dilakukan oleh anggota Tentara Nasional Indonesia, Tesis, Jember: Program Studi Magister Ilmu Hukum, Fakultas Hukum Universitas Jember, 2015, hlm. 169 - 170

${ }^{16}$ L.j Van Apeldoorn dalam Shidarta, Moralitas Profesi Hukum Suatu Tawaran Kerangka Berfikir, (Bandung : PT.REVIKA Aditama ),2006, hlm. 82-83 
didasarkan pada undang-undang. Dalam hal yang terakhir berarti keadilan substansial terpinggirkan oleh keadilan procedural. ${ }^{17}$

Pada Putusan MK Nomor 16/PUU-XVIII/2020, yang pada intinya mengajukan gugatan judicial review terkait dengan Pasal 66 ayat (1) UUJNP. Majelis hakim harus bersikap adil serta memikirkan dampak yang luas karena putusannya akan membentuk norma baru atau hukum baru yang berdampak pada maysarakat luas tidak hanya PJI dan Notaris. Pada Pada Putusan MK Nomor 16/PUU-XVIII/2020, hakim sekalipun sulit dianggap adil sepenuhnya, karena putusannya pasti ada pihak tetap merasa dirugikan. Akan tetapi disini Hakim MK wajib menerapkan teori kebenaran dan keadilan dengan benar dalam pertimbangan putusannya. Disinilah dituntut hakim-hakim yang terampil tidak hanya ahli dalam menerapkan undang- undang saja, namun berani melakukan tindakan tindakan progresif untuk mewujudkan keadilan yang sebenarnya, dalam konteks ini, dibutuhkan kecerdasan dan kearifan hakim dalam memutus perkara. ${ }^{18}$

Kepastian hukum dengan keadilan dianalogikan oleh Sudikno Mertokusumo sebagai dua kutub yang saling tarik menarik dalam penegakan hukum yaitu kutub keadilan dan kepastian. ${ }^{19}$ Pada dasarnya jika keadilan dan kepastian hukum sulit untuk ditegakkan secara bersama-sama maka diharapkan penegakan hukum tindak pidana notaris berdasarkan Pasal 66 ayat (1) UUJN dan diperkuat dengan adanya Putusan MK Nomor nomor 16/PUU-XVIII/2020 dapat dilakukan dengan koordinasi antara penegak hukum baik kepolisian, kejaksaan dan kehakiman dan kementrian hukum dan HAM beserta MKN. Kepastian hukum sangat penting dalam penegakan hukum tindak pidana yang dilakukan oleh notaris, karena jika terjadi ketidakpastian hukum akan menimbulkan "social disorganization atau kekacauan sosial. ${ }^{20}$

\section{Kemanfaatan}

Jeremy Bentham menyatakan bahwa, hukum bertujuan menjamin adanya bahagia sebanyak-banyaknya pada orang. ${ }^{21}$ Judicial review yang diajukan oleh pemohon dalam perkara Nomor 16/PUU-XVIII/ 2020 terkait dengan ketentuan Pasal 66 ayat (1), menurut pendapat penulis bahwa dalam hal ini majelis hakim lebih menitikberatkan pada kepastian hukum dan kemanfaatan. Kepastian hukum dalam putusan tersebut terlihat pada hakim MK lebih cenderung mempertahankan norma-norma dalam UU yang pernah diajukan sebelumya sama dengan masalah konstitusionalitas dalam Putusan Mahkamah Konstitusi Nomor 22/PUU-XVII/2019, dimana MK berpendapat bahwa Pemohon tidak memahami norma Pasal 66 ayat (1) UUJNP tersebut secara utuh dalam kaitannya dengan ketentuan lain dalam UU a quo termasuk kewenangan dari MKN. Adanya persetujuan MKN tidak bertujuan untuk mempersulit proses penyidikan atau keperluan pemeriksaan terhadap notaris karena hal tersebut telah diantisipasi dengan adanya ketentuan Pasal 66 ayat (3) UUJN. ${ }^{22}$

17 Yunanto, Menerjemahkan keadilan Dalam Putusan Hakim, Jurnal Progresif, Vol. 7, No. 2, Oktober 2019,

18 Ibid., hlm. 202

${ }^{19}$ Sudikno Mertokusumo, Bunga Rampai Ilmu Hukum, Liberty, Yogyakarta, 1984, hlm. 6

${ }^{20}$ L.j Van Apeldoorn dalam Shidarta, Op, Cit., hlm. 85

${ }^{21}$ Ibid., hlm. 78

${ }^{22}$ Lihat Putusan MK Nomor 16 / PUU -XVIII, hlm. 75 - 76 
Adapun putusan MK Nomor 16/PUU-XVIII/ 2020 menurut penulis dengan adanya MKN sebagai lembaga yang memberikan izin kepada penegak hukum untuk dapat memanggil notaris dan memberikan keterangan akta yang dibuatnya kepada penegak hukum, justru memberikan perlindungan hukum bagi notaris dan maysarakat yang menggunakan jasa notaris berupa jaminan kerahasiaan akta yang dibuat oleh notaris.

Putusan hakim MK pada praktiknya dapat dilihat berdasarkan tujuan hukum yang menjadi pertimbangan, seperti sebagai berikut:23

a. Dari sudut pandang ilmu hukum positif normatif atau yuridis dogmatis, tujuan hukum dititikberatkan pada segi kepastian hukumnya;

b. Dari sudut pandang filsafat hukum, tujuan hukum dititik beratkan pada segi keadilan;

c. Dari sudut pandang sosiologi hukum, tujuan hukum dititikberatkan pada segi kemanfaatan.

\section{Penutup}

Berdasarkan uraian sebelumnya, maka dapat ditarik kesimpulan, pertama Majelis Kehormatan Notaris (MKN) sejak dari awal terbitnya UUJNP tidak menghalangi penegakan hukum.

Adapun pandangan hakim MK Nomor 16/PUU-XVIII/2020 dalam pertimbangan hakim terkait dengan gugatan pemohon menyatakan bahwa Pasal 66 ayat (4) sangat diperlukan dalam menciptakan kepastian hukum yang adil terhadap batas kewenangan MKN memberikan persetujuan bagi penyidik, penuntut umum dan hakim dalam melakukan pemanggilan terhadap notaris ataupun memeriksa berkas-berkas lain untuk keperluan peradilan sebagaimana dimaksud Pasal 66 ayat (1) UUJNP.

Majelis Hakim MK dalam menajatuhkan putusan Nomor 16/PUU-XVIII/2020 lebih menitikberatkan pada kepastian hukum dan kemanfaatan. Kepastian hukum terlihat dalam majelis hakim tetap mempertahankan Pasal 66 ayat (1) UUJN sedangkan kemanfatan terlihat dalam majelis hakim tetap mempertahankan lembaga MKN dimana melindungi notaris dalam menjalankan tugas profesinya serta masyarakat umum yang menggunakan jasa notaris terkait dengan kerahasaiaan akta yang dibuat oleh notaris. Kerahasiaan merupakan unsur penting bagi masyarakat umum yang menggunakan jasa notaris karena jika tidak ada kerahasiaan akta yang dibuat oleh notaris menimbulkan ketidak percayaan publik atau masyarakat yang berdampak kepada privasi keamanan pada mayasrakat pengguna jasa notaris.

\section{Daftar Pustaka}

\section{Buku}

Kadir Muhammad, Abdul, Hukum Dan Penelitian Hukum, Citra Aditya Bakti, Bandung, 2004.

Mertokusumo, Sudikno, Bunga Rampai Ilmu Hukum, Liberty, Yogyakarta, 2009.

${ }^{23}$ Yunanto, OP, Cit., hlm. 203 
Shidarta, Moralitas Profesi Hukum Suatu Tawaran Kerangka Berfikir, Revika Aditama, Bandung, 2006.

\section{Hasil Penelitian/Tugas Akhir}

Juleni, Implementasi Pemeriksaan Notaris Oleh Majelis Kehormatan Notaris Atas Dugaan Melakukan Tindak Pidana Berdasarkan Peraturan Menteri Hukum dan Hak Asasi Manusia Nomor 7 Tahun 2016 tentang Majelis Kehormatan Notaris, Tesis, Program Magister Kenotariatan, Fakultas Hukum, Universitas Sebelas Maret, Surakarta, 2018.

Sanjaya, A. W. Kewenangan penyidikan tindak pidana pencucian uang yang dilakukan oleh anggota Tentara Nasional Indonesi $a$, Tesis, Jember: Program Studi Magister Ilmu Hukum, Fakultas Hukum Universitas Jember, 2015.

\section{Jurnal}

Apita Maya, Evi, Kedudukan Dan Kewenangan Majelis Kehormatan Notaris Dalam Pembinaan Notaris, Jurnal IUS, Volume 5, Nomor 2, Agustus, 2017.

Hernawan \& Munssyarif Abdul Chalim, Udi, Kewenangan Majelis Kehormatan Notaris Wliayah Dalam Memberikan Persetujuan Terhadap Pemanggilan Notaris Oleh Penegak Hukm, Jurnal Akta, Volume 4 Nomor 3, Tahun 2017.

Pancaputri, Rachmaad Syafaat, Istislam, Azisia, Perlindungan Hukum Bagi Notaris Dalam Proses Penyidikan Terhadap Notaris Yang Diduga Melakukan Tindak Pidana Terkait Dengan Putusan Mahkamah Konstitusi Nomor 49 / PUU-X / 2012 (Studi Di Kantor Polisi Resort Kota Malang ), Jurnal Media. neliti, didownload pada https://media.neliti.com/media/publications/118683-IDperlindungan-hukum-bagi-notaris-dalam-r.pdf .

Sumiarti, Djodi Suranto, Yennie K Milano, Endah, Fungsi Majelis Kehormatan Notaris Ditinjau Dalam Perspektif Perlindungan Jabatan Notaris Dan Kepentingan Umum, Jurnal Pakuan Law Review, Volume 1 Nomor 2, Julli - Desember 2015.

Yunanto, Menerjemahkan keadilan Dalam Putusan Hakim, Jurnal Progresif, Vol. 7, No. 2, Oktober 2019.

\section{Peraturan Perundang-Undangan}

UUD 1945

Undang-Undang Nomor 2 Tahun 2014 Tentang Jabatan Notaris, Lembaran Negara Republik Indonesia Tahun 2014 Nomor 3, TLN Nomor 5491.

Peraturan Menteri Hukum Dan Hak Asasi Manusia Republik Indonesia Nomor 7 Tahun 2016 tentang Majelis Kehormatan Notaris.

\section{Putusan Pengadilan}

Putusan Mahkamah Konstitusi Nomor 16/PUU-XVIII/2020 Tentang Persetujuan Majelis Kehormatan Notaris Atas Pemanggilan Notaris Dalam Pemeriksaan Tindak Pidana. 